Revue Française de Civilisation Britannique

\title{
The Privatisation of Asylum Accommodation in the UK: Winners and Losers
}

La privatisation de l'hébergement pour les demandeurs d'asile: les gagnants et les perdants

\section{David Fée}

\section{(2penEdition}

\section{Journals}

Electronic version

URL: https://journals.openedition.org/rfcb/8082

DOI: $10.4000 /$ rfcb.8082

ISSN: 2429-4373

\section{Publisher}

CRECIB - Centre de recherche et d'études en civilisation britannique

\section{Electronic reference}

David Fée, "The Privatisation of Asylum Accommodation in the UK: Winners and Losers", Revue

Française de Civilisation Britannique [Online], XXVI-2 | 2021, Online since 05 janvier 2021, connection on 28 juin 2022. URL: http://journals.openedition.org/rfcb/8082 ; DOI: https://doi.org/10.4000/rfcb.8082

This text was automatically generated on 5 January 2022.

Revue française de civilisation britannique est mis à disposition selon les termes de la licence Creative Commons Attribution - Pas d'Utilisation Commerciale - Pas de Modification 4.0 International. 


\section{The Privatisation of Asylum Accommodation in the UK: Winners and Losers}

La privatisation de l'hébergement pour les demandeurs d'asile : les gagnants et les perdants

David Fée

\section{Introduction}

1 Britain has a long tradition of hosting and welcoming migrants and refugees, being one of the first 13 signatories of the 1951 Geneva Convention on refugees. Housing, as underlined by many studies, ${ }^{1}$ is key to their integration into British society. However, while the national housing crisis and the changes in house prices attract much media attention, the housing problems refugees face do not get much press coverage, apart from by the specialist media (Inside Housing for instance). When they do, it is mostly from the tabloid press which is quick to denounce the 'over indulgent' access to social housing migrants and refugees are said to enjoy. ${ }^{2}$

2 The housing conditions of asylum seekers are even more problematic. They are not only constrained by the national housing shortage but have also been redefined following a major structural overhaul of asylum accommodation in the past 10 years which amounts to a privatisation of the system, although its operation and regulation mark it apart from the traditional privatisation of utilities.

3 This article will review and analyse the transformations of the system designed by the UK authorities to accommodate asylum seekers, in order to assess the extent to which it has been privatised and the consequences of these transformations. First, I will review the concept of privatisation in order to try and understand the specificities of the privatisation policies applied to asylum accommodation. Then, I will locate housing within the controversial issue of asylum and migration to the UK, before exploring the 
legislative changes introduced by successive governments to the asylum accommodation programme and their motivations. I will next assess the consequences of and the problems thrown up by this privatisation, before concluding on how privatisation has played out in a policy area largely regulated by international law.

4 This paper only focuses on asylum seekers, namely someone who has arrived independently in the UK, has applied for asylum and is awaiting a decision on whether they will be granted refugee status or not. ${ }^{3}$ I shall not look into the housing of other categories of migrants such as resettled people ${ }^{4}$ or even refugees. Besides, I shall not look at the devolved nations in detail but at the UK in general as immigration is not a devolved matter.

\section{The Privatisation of Public Services in the UK}

Along with the USA, the UK has been a driving force behind the privatisation of the world's economy for the past 40 years. In the UK, this privatisation momentum was unleashed by the Conservative government formed after Margaret Thatcher's electoral victory in 1979 and the coming to power of the so-called New Right. ${ }^{5}$ The determination of successive Conservative governments to privatise the economy can be accounted for by the neoliberal component of the New Right. Indeed, its philosophy is by and large averse to state intervention in the economy ${ }^{6}$ and has been summarised by Nicholas Bosanquet by a thesis and an antithesis: Bosanquet argues that for the New Right "society has a natural tendency to order and the economy a natural tendency to growth". Conversely, he argues, for the New Right the negative result of state intervention is that as "politicisation" grows, politics becomes concerned with vote-buying and public spending and taxation get out of control. ${ }^{8}$

6 It follows from this outlook that government intervention is seen as likely to create chaos and disrupt these natural tendencies and that the role of government should be kept to a minimum, namely upholding law and order, justice, national security and setting the right framework for the market to thrive. The New Right's determination to privatise derives from the belief that the market is the best mechanism to allocate resources as it is thought to match supply and demand and achieve a balance if left to its own devices. Privatisation also derives from the need to secure accumulation and profit by means of competition between individuals and companies in order to fuel the market economy. "Because this acquisitive momentum produces material abundance, it is claimed that self-interest benefits society as a whole". ${ }^{9}$

7 Because of these ideological premises, in the UK, the state has been the subject of " $a$ permanent revolution"10 for four decades and privatisation has been one aspect of this revolution. This has taken many forms. Since 1980, reforms have been introduced in the UK to change and privatise what Le Grand and Robinson called one year into Thatcher's second term "the three modes" of state activity: provision, subsidy and regulation. ${ }^{11}$ Successive governments, not only Conservative but also New Labour, ${ }^{12}$ have upheld a 'small state' consensus and sought to curtail these three modes, reducing state provision, subsidies, and regulation.

8 The welfare state and public services have been a prime target for the New Right in the UK. Indeed, the foundations on which post-war public services were built were criticised by New Right proponents and said to be in need of reforms for a number of reasons: they were said to be too costly, to favour the middle classes more than the 
poor, ${ }^{13}$ to be controlled by vested interests and finally to limit choice. ${ }^{14}$ Their privatisation has not always been visible as it does not always involve the replacement of the state by the market ('denationalisation') or contracting out, but can be limited to "the shift from one form of intervention to another one or the encouragement of the third sector". ${ }^{15}$ The contours of public services have become blurred as these shifts have sometimes morphed into "the privatisation of the production of a service that is still state financed". ${ }^{16}$ This is especially true in the field of housing where from 1988 until recently the state-subsidised the voluntary sector to build social housing. More specifically, the privatisation of housing in the UK has involved denationalisation (right to buy), liberalisation (increasing the role of the private and third sectors) and contracting out (of its management to new structures such as TMOs and ALMOs ${ }^{17}$ or the private sector). Besides, the direction of change, the nature and extent of privatisation can be constrained by the "previous pattern of state provision and intervention", as some scholars argue. ${ }^{18}$

Where the state has not been privatised, its operation has been profoundly reformed through a "managerialisation" process designed to remodel it on the lines of the private sector. ${ }^{19}$ This is said to have occurred in two stages: first, in the 1980 s, the onus was on cost control, performance indicators and targets; then, from the late 1980s on, decentralisation and quasi-markets were introduced. ${ }^{20}$ In order to reform public services, successive governments since 1980 have drawn on a number of mechanisms including fragmentation, competition, private management practices, economies (savings), the creation of a managers' tier, performance assessment and payment by result. $^{21}$

The result of this revolution has been, as LeGrand and Robinson predicted as early as 1984, that: "the state will be involved through subsidisation and through helping entrepreneurship by others, rather than through direct public provision". ${ }^{22}$

Housing in the UK has been significantly impacted by these reforms and has been in the vanguard of this privatisation programme for a number of reasons: first, because it breached a number of New Right principles (control of the money supply, reduction of the Public Sector Borrowing Requirement ${ }^{23}$ and freedom of choice). ${ }^{24}$ Second, the number of winners was large and visible (those former tenants who have become home owners under the Right to Buy ${ }^{25}$ ) while losers were also numerous but invisible (taxpayers footing the bill). ${ }^{26}$ Lastly, housing was privatised because it is mostly a private good and local authorities were thought to be inefficient and dominated by vested interests. ${ }^{27}$ One outcome of this privatisation process in the housing sector in general has been its residualisation, namely the decline of the size of the council sector and the concentration of poorer households in it. ${ }^{28}$ The commodification of the housing sector through the sale of the more attractive council homes has indeed reinforced social stratification: by $2016 / 17$, only $43 \%$ of social rented households were in full or part-time work, $21 \%$ were inactive and three quarters were in the bottom $40 \%$ of the income distribution in England. ${ }^{29}$ It has also reinforced the concentration of ethnic minorities with all ethnic groups bar Indians, Mixed, other Whites and Chinese being more likely to live in social housing than white British. ${ }^{30}$ The other outcome has been that the Right to Buy has generated more than $£ 58$ billion in capital receipts for the government, more than any privatisation programme since 1980 in the UK. ${ }^{31}$

12 As we shall see in the next section, the privatisation of asylum accommodation derives in part from a desire not to compound the socio-economic characteristics of the social 
sector; as in the case of the privatisation of council housing, it stems from a desire on the part of central government to make savings. We shall to turn to the question of the privatisation of asylum accommodation proper and examine it against the background of asylum migration first.

\section{Asylum Seekers in the UK: a Controversial Issue}

13 Paradoxically, although the number of asylum seekers in the UK is much lower than in the early 2000s, the salience of the question in public opinion has increased and it has been increasingly subject to political debate and instrumentalisation. As a result, governments have introduced a number of legislative changes in order to create a "hostile environment" ${ }^{32}$ which bears on the housing circumstances of asylum seekers.

In 2018, 5.7\% of all international immigrants (namely "people who change their country of residence for at least one year") were classified as asylum seekers. The number of asylum applications to the UK rose from 1989 onwards, peaked in 2002 at 84,132 and then fell sharply to reach a twenty-year low point of 17,916 in 2010, before rising again to reach 35,566 in 2019. ${ }^{33}$ These figures do not include resettled people as explained above. ${ }^{34}$ Asylum seekers migrate from all parts of the globe and there is no predominant geographical area of origin, although only $6 \%$ come from the Americas or Oceania: in 2019, 29\% of asylum applicants were nationals of Asian countries, 27\% were nationals of Middle Eastern countries, $24 \%$ were nationals of African countries, and $14 \%$ were from Europe..$^{35}$ Compared to other European countries of reception, the UK has a low ratio of asylum seekers: in 2019, there were around 5 asylum applications for every 10,000 people residing in the UK, while across the EU28, there were 14 asylum applications for every 10,000 people. The UK was therefore below the average among EU countries for asylum applications per head and ranked $17^{\text {th }}$ among EU28 countries on this measure. ${ }^{36}$

Two key figures matter regarding housing provision. First, the percentage of asylum applicants whose application was refused, since in theory their legal right to housing comes to an end on refusal (see next section): the rate of refusal reached its highest point at $88 \%$ in 2004 . After that, the percentage of applicants refused asylum fell to $59 \%$ in 2014 , then rose again, before dropping to $48 \%$ in $2019 .{ }^{37}$ The second indicator is the percentage of appeals that are successfully lodged, since persons appealing who are successful have their right to housing reinstated: this stood at its lowest point in 2004 at $18 \%$, increased to $42.2 \%$ in 2015 , before falling back to $35.4 \%$ in $2018 .^{38}$

Although asylum seekers account for a lower proportion of international migrants in the UK than in many European countries, they have become caught up in the immigration debate and their social and housing rights have been affected as a result. Following Theresa May's 2012 statement about creating "a hostile environment", the political determination to create such an environment for migrants is often associated with the coalition government that was in power between 2010 and 2015. However, this policy agenda originated earlier, in the mid-1990s. Even before the Coalition was formed, legislative changes, ministers' statements, ${ }^{39}$ and increased European migration following the 2004 expansion of the $\mathrm{EU}$, had led to a change in public opinion and the greater salience of the issue of migration. This contributed to the perception that migrants benefited unfairly from social housing and other services, despite studies by the Equality and Human Rights Commission and the Local Government Association 
showing that the view that "migrants are jumping social housing queues" is unfounded.

This agenda means that UK immigration policy has been "at the forefront of a growing European 'restrictionism' towards refugees and asylum seekers" which has been driven both by ideological and economic considerations. ${ }^{41}$ In the UK, "restrictionism" started rising to the top of the political agenda during the Major years and stayed there during the New Labour years when the party's immigration policy was driven by two principles: limitation of public expenditure and keeping an image of political toughness. ${ }^{42}$ It has led to new entry requirements and restrictions to welfare for asylum seekers once in the UK.

This new approach to immigration and more particularly asylum manifested itself most prominently in 1998 when the New Labour government published a White Paper entitled Fairer, Faster and Firmer, A Modern Approach to Immigration and Asylum. ${ }^{43}$ It heralded a reform of the existing system with a view to creating "a new covenant" based on "fulfilling the mutual obligations [...] that exist between the Government and those seeking asylum". ${ }^{44}$ The document illustrated a hardening of discourse and policy towards asylum seekers and continuities with previous Conservative governments. While underlining the contribution international migration made to the UK, it pledged "to deal quickly and firmly with those who have no right to enter or remain [in the UK]" and to tease out "genuine applicants" from "abusive claimants", so as to "to plan and allocate resources more flexibly in order to minimise costs overall [...] to the taxpayer". ${ }^{45}$

As a result of this political consensus on an 'exclusive citizenship"46, asylum seekers no longer have similar rights in the field of housing to those granted to refugees and other persons in need. From the mid-1990s onwards, a series of measures have curtailed their housing rights as well as their choice. First, the 1993 Asylum and Immigration Appeals Act abolished local authorities' duty to house asylum seekers permanently. Second, the 1996 Asylum and Immigration Act together with the 1996 Housing Act defined two categories of asylum seekers (port-of-entry and in-country) and removed single asylum seekers from the priority need categories of the population whom local authorities have had a duty to house since 1977 if at risk of homelessness. ${ }^{47}$ More generally, successive legislative changes have reduced their welfare rights: in 2002, section 55 of the Nationality, Immigration and Asylum Act removed support from those who did not make a claim "as soon as reasonably practicable" and "recourse to public funds" was no longer possible for asylum relatives. ${ }^{48}$ In 2011, support was further reduced, with the abolition of the Refugee Integration and Employment Service, the service designed to help asylum seekers move out of the asylum system into real life, once they had been granted refugee status. ${ }^{49}$

However, the politicisation of the asylum issue and more generally of immigration in the UK over the last 30 years has not only impacted the housing rights of asylum seekers and led to the rise of what some term "crimmigration" ${ }^{50}$ : coupled with austerity measures, it has also brought about the privatisation of asylum accommodation after 2010. 


\section{The Privatisation of Asylum Accommodation}

21 The housing rights of asylum seekers in 2020 are tightly defined and housing is part of the help asylum seekers are entitled to under three circumstances: while the Home office is reviewing their application (section 95 of the Asylum and Immigration Act 1999) if they have no means of their own; while assessing whether they are eligible for support (section 98); and when an applicant has been refused asylum but has not yet left the country (section 4). Asylum seekers cannot choose where they will be accommodated and the current Home Office policy revolves around dispersing them around the country. On arrival in the UK they should be housed in Initial Accommodation (IA) centres (there were seven in 2017) for up to 19 days while the Home Office assesses whether they are eligible for accommodation and if so dispersed to settled accommodation. However, if no place is available in IA, applicants can be temporarily housed in emergency accommodation (hotels, hostels, or B and Bs). If an asylum application is accepted, "applicants have 28 days to secure housing and a means to support themselves before their entitlements under section 95 are stopped". ${ }^{51}$ They become refugees and must leave the accommodation provided, and the local authority then has a duty to rehouse them. However, if their application is rejected and they are one of the statutory priority categories, the local authority must frequently also rehouse asylum seekers temporarily while they await deportation or appeal so that they do not become homeless.

At the end of December 2018, statistics showed that there were 43,549 asylum seekers benefiting from section 95 assistance, of whom 40,072 were living in dispersal accommodation, namely not in IA anymore. The North East of England had the highest proportion of dispersed asylum seekers relative to its population ( 6 for 10,000) and the South East the lowest. Glasgow and Liverpool had the highest numbers as far as councils were concerned. That $62 \%$ of local authorities had no asylum seekers in 2018 highlights their concentration in some areas of the country. ${ }^{52}$

The privatisation of asylum accommodation is the outcome of a series of measures that have gradually shifted the system away from local authorities towards private contractors and sub-contractors. The formation of the Coalition in 2010 was a turning point, although key changes introduced during the New Labour years paved the way for this development.

Before 1999, it fell upon the local authority where asylum seekers made a claim for asylum to provide accommodation. The problem was that most were made in London and the South East. In order to relieve the pressure on these areas, the newly elected New Labour government announced changes to support arrangements in the 1998 White Paper previously mentioned (Fairer, Faster and Firmer: A Modern Approach to Immigration and Asylum) in order to move towards a more integrated approach,,$^{53}$ and to a centralised system. Asylum seekers arriving in the UK would henceforth fall under the jurisdiction of a new body, the National Asylum Support Service (NASS), run by the Home Office through regional consortia whose remit was to secure accommodation from various providers through contracts. ${ }^{54}$ These could be voluntary bodies, local associations or companies from the private sector, although in the initial funding round local authorities dominated before being replaced by private sector entities after 2006 when council housing for asylum seekers became controversial. ${ }^{55}$ Accommodation was to be provided on a "no choice" basis and was construed as a "safety net". ${ }^{56}$ The 
two key motivations behind the reform were greater efficiency through "rationalisation" and cost-cutting: the existing system was said to cost $£ 400$ million and likely to rise to double that amount by $2000 / 01 .{ }^{57}$ The reform was implemented following the passing of the 1999 Asylum and Immigration Act. Further privatisation took place before 2010: in 2002 under the Nationality, Immigration and Asylum Act, a programme of reception centres for asylum seekers was initiated (IA) and contracted out to the private sector. ${ }^{58}$ The new arrangements resulted in a system of 22 separate contracts with 13 different suppliers (a mixture of local authorities, private providers and voluntary organisations) by $2012 .^{59}$

The formation of the Coalition in 2010 ushered in a further and deeper round of privatisation. The privatisation of asylum accommodation was retained (IA centres and the increasing use of private landlords) and in addition to that the contracting process was privatised. Since 2012, the accommodation of asylum seekers has been provided through contracts managed by six regional Commercial and Operational Managers Procuring Asylum Support Services (COMPASS). By 2018, three private companies (Serco, G4S, and Clearsprings) each held two of these contracts and operated "a supply network of contractors, sub-contractors and private landlords". ${ }^{60}$ Under the new contract system, the Government aimed to make $£ 140$ million worth of savings in the first round. ${ }^{61}$ These companies were known to the Government as they already provided services to the Government, but only Clearsprings had some housing experience. Contracts were given for five years, but in 2016 the government announced that they would be extended until 2019 and that a new round of contracts would start as of 2019.62 An invitation to tender was put out in November 2017 for 10-year contracts worth $£ 4$ billon, in the seven regions covered by the UK Visas and Immigration office (the three devolved governments plus four groupings of English regions). The new contracts, known as Asylum Accommodation and Support Service Contracts (AASC), were awarded in January 2019 to Serco, Mears Group and Clearsprings Ready Home.

Serco won the new AASC contracts for the Midlands, the East of England, and the North West, worth $£ 1.9$ billion over ten years. The company was originally founded in 1929 as the British division of the Radio Corporation of America (RCA), and became a provider of public services following a management buy-out in 1987 and stock exchange listing in 1988. Today Serco employs more than 50,000 people worldwide. It describes its mission as "the delivery of essential public services [...]in defence, transport, justice, immigration, healthcare and other citizen services" ${ }^{63}$ In 2019, it had an overall revenue of $£ 3,248$ million and profits of $£ 102.5$ million, across four continents. It aims to "improve the performance of public services [...]" and prides itself on that fact that "a strong public sector ethos runs through [their] organisation". ${ }^{64}$ Mears Group was awarded contracts for the North East, Yorkshire, Humberside, Northern Ireland, and Scotland. Similar to Serco, Mears was founded in 1988. It is smaller, with over 15,000 employees in 2016, and a turnover of $£ 905.1$ million in 2019. Mears only specialises in housing-related services (maintenance, management, development, care and support and planning) and manages 11,000 homes every day. Clearsprings/Ready Homes was awarded contracts for Wales and the South of England. It was established in 2000, is a subsidiary of Clearsprings and has been providing homes to central and local government for 14 years. It states that it has a portfolio of 15,000 homes and prides itself on "providing value for money, quality and transparency". ${ }^{65}$ 
Under the COMPASS terms as well as the AASC ones, contractors need to take a number of factors into consideration when suggesting accommodation to the Home Office, such as the concentration and availability of accommodation, the capacity of local public services, or the level of risk of social tension if the number of asylum seekers increases. ${ }^{66}$ Their performance is measured against a number of Key Performance Indicators (KPIs) (9 for COMPASS including three for accommodation standards) designed to improve the quality of services. When problems are brought to the attention of the providers, they must address and solve them within a specific timescale or face financial penalties. ${ }^{67}$ Yet despite this legal framework, a number of issues/problems have arisen.

\section{The Consequences of Privatisation} contractors are not answerable to local authorities although they operate within their boundaries. As Andy Burnham (Mayor of Greater Manchester) and other council leaders have complained, the new arrangements have created an unequal partnership between the Home Office, the local authorities and the contractors: this was due to the Home Office's refusal to share "risk management information and contingency plans" 69 (in contracts), but above all to the lack of local authority oversight: although the asylum dispersal scheme can only operate with their agreement, on a voluntary basis, local authorities have no inspection or sanction power nor can they impose the same housing standards regulations within their boundaries. ${ }^{70}$ Besides, although the housing provider must consult with the local authority regarding the accommodation envisaged, the latter only has 72 hours to consider the request and if turned down on the grounds of health and safety issues, the provider can "seek permission from the Home Office to override the local authority's objections". ${ }^{71}$ The lack of power on the part of local authorities is all the more paradoxical as they have to pay for extra services provided to asylum seekers (health, education) although they receive no extra funding from the central government unlike for Resettlement Programmes. ${ }^{72}$

The discontent expressed by local authorities is also caused by a second problem created by the privatisation of asylum accommodation: the frequent use of substandard dwellings by contractors. The standards of settled accommodation provided by contractors are regulated by the Key Performance Indicators applying to accommodation (KPI 4/5/6/7, see above) and should conform to them: this means that contractors should provide accommodation that is safe, without any severe defects and be well-maintained. Furthermore, they should make it possible for asylum seekers to raise complaints and contractors should contractually address these within five days or 
respond to any emergency within the specified response time. ${ }^{73}$ Properties should be inspected by providers (who are one and the same) at least once a month and every time an asylum seeker moves out of a property. Besides, the Home Office is supposed to inspect one third of all properties in a contract area every year.

However, parliamentary reports have repeatedly underlined a number of failings: these include the presence of vermin, of asbestos, cleanliness issues, inadequate facilities or furnishings, and failing heating systems. The accommodation provided is inspected by the contractor (with potential conflicts of interest even if subject to key performance indicators), but the local authority has no power to conduct inspections. These problems were confirmed by an Independent report in 2018 highlighting that only $24 \%$ of the properties inspected complied with the Compass requirements according to the Home Office's own inspectors, while $43 \%$ were not fit for purpose. ${ }^{74}$ As the ICIBI report underlined, the Home Office, with a team of nine Contract Compliance Officers for the whole country, was not able to meet its inspection targets. ${ }^{75}$

Initial accommodation run by the private sector since 2020 poses even more problems. Parliamentary reports have underlined that bathrooms and showers facilities in such centres are sometimes dirty, pregnant women not always fed adequately and health checks are not carried out properly so diseases are not always picked up. ${ }^{76}$ There is sometimes not enough food, children are not always schooled and providers do not always fulfil their obligations to provide transport to medical appointments. ${ }^{77}$ When hotels are used in emergency situation, they can be substandard or unfit as the same criteria are not applied as for settled accommodation.

When standards are not up to the key performance indicators, the Home Office can impose fines or a service credit. Reports show that the records of the three contractors from 2012 to 2019 varied widely: while Clearsprings was never sanctioned for missing targets between 2012 and 2017, and G4S was not fined in 2015 and 2016, Serco was fined almost every year. ${ }^{78}$ Worryingly, the subcontractors carrying out inspections on behalf of the contractors did not appear to have the same definition of "urgent defects" and "emergency defects" as the Home office, which itself did not agree with local authorities. ${ }^{79}$

One issue that privatisation was meant to solve but that still endures for different reasons is the concentration of asylum seekers. The system introduced in 1999 that was privatised in 2012 was meant to disperse asylum seekers away from London and the South East. While this geographical shift has been achieved, it has been at the expense of the Northern councils that have taken part in the programme. Indeed, the cost saving objectives of the initial programme have been compounded by the austerity measures introduced by the Coalition after 2010. This has resulted in asylum seekers being sent away from the existing communities ${ }^{80}$ and cheaper accommodation being sought by contractors in order to keep within the financial constraints of the Home office contracts or to minimize their losses. Two problems have surfaced: on the one hand, in these cheaper and often poorer areas where asylum seekers are concentrated, deprived communities can be unwelcoming and suspicious of newcomers and an influx of asylum seekers can push up local private rents or reduce accommodation supply, thus leading to local tensions.$^{81}$ On the other hand, some voluntary local authorities are not able to provide accommodation as a consequence of local high housing prices ${ }^{82}$ The concentration of asylum seekers may not be visible at first sight as although the cluster limit may not be reached ( 1 for 200 residents) at local authority level, there may be a 
high concentration at ward level where the limit does not apply because of cheap housing being located in a few deprived wards. The problem is made worse by the fact that while the number of asylum seekers almost doubled between 2012 and 2019, the number of local authorities taking part in the scheme went down from 150 to only 121 (out of 453). ${ }^{83}$

The eviction of some asylum seekers from dispersal accommodation has drawn media attention too: in a number of cases, where there are no health considerations and an application has been rejected by the Home Office and the applicant refuses to leave, locks on the property were changed by Serco while the applicant was out. ${ }^{84}$ This can also happen when the applicant has received a positive reply but has not secured another accommodation within the 28 legal days and so has not left. However, it appears that Serco also ended up paying the rents of applicants when there were (child) welfare considerations and the Home Office stopped funding. ${ }^{85}$

Most of the problems described above derive from the new and faulty governance of the asylum system. However, some, such as service fragmentation, were already underlined in 2002. ${ }^{86}$ As the 2017 House of Commons report then noted, the main cause of the current problems is that "although the system of three providers looks straightforward on the surface, below it lies a complex network of contractors, subcontractors and private providers" ${ }^{87}$ Indeed, the contractors themselves are required to source accommodation provision from various providers. ${ }^{88}$ For instance, from September 2012 to 2016, Serco subcontracted asylum housing to Orchard and Shipman, a specialist lettings agency, in Scotland and Northern Ireland. However, following complaints about O\&S's treatment of asylum residents and housing conditions and Serco appearing before the Home Affairs committee, O\&S's operations were transferred to Serco. ${ }^{89}$ During the proceedings, the committee's chair underlined that Serco subcontracted its operations to 20 providers, who themselves, unbeknownst to Serco, sometimes subcontracted their operations too. As the CEO of Serco explained, part of the problem was that Serco only managed the estate but subcontractors were in charge of the maintenance of their properties. ${ }^{90}$

\section{Conclusion}

Asylum accommodation is illustrative of the privatisation revolution that has swept the UK since the 1980s in many ways. As in other policy areas (education to a lesser degree), local authorities have been deprived of most of their power and are no longer service providers but only facilitators. They have all the risks but no tools to manage these. ${ }^{11}$ Privatisation has been motivated by a desire on the part of successive governments to cut costs, streamline the existing system and paradoxically recentralise it (i.e. the Home Office negotiates accommodation contracts directly with a handful of contractors and defines targets and indicators), as well as a determination to diffuse this political issue in this particular case. However, unlike for utilities, privatisation has worked its way through contracting, subcontracting; the system remains a hybrid one since state subsidies are used to provide private goods (private accommodation); looking at the reform through LeGrand's grid of analysis, it is clear that provision has been privatised, but subsidy and regulation have not. The general result is a loss of accountability, as private contractors are not accountable to local authorities and, as a consequence, to local residents and voters. On the face of it, the governance of asylum 
accommodation has become simpler, more top-down, but underneath it has developed into a complex network of national, local and sometimes international actors (Serco), whose primary motivation is thought to be to use housing provision as a stepping stone to obtaining bigger government contracts. ${ }^{92}$

Despite repeated recommendations by the ICIB as well as the Home Affairs Committee, the Home Office has decided to retain the post-2012 system, insisting that any transfer of responsibility to local authorities would make the system less rigorous and "reduce the accountability of the Home Office and the ability to hold providers to account". ${ }^{93}$ It is hard not to read behind this decision the usual mistrust all UK governments have displayed towards local authorities since 1979. In a written statement in 2019, Caroline Nokes, the then Minister of State for immigration, announced that the new contracts would provide improvements on existing arrangements such as a requirement for accommodation providers to liaise closely with local authorities, to work with the local community and voluntary organisations, to have a clear management and inspection plan, to set clear requirements for standards and inform asylum seekers better about their rights. ${ }^{94}$ However, although more central government funding was pledged by her predecessor to improve the system, ${ }^{95}$ value for money seems to remain a top priority behind the new contracts. ${ }^{96}$ One can only hope asylum seekers will benefit from better housing conditions. If not, only the Home Office and private contractors will gain from the renewal of a much-criticised system.

\section{BIBLIOGRAPHY}

Aliverti, Ana, Crimes of Mobility: Criminal Law and the Regulation of Immigration (London, Routledge, 2013).

Bosanquet, Nicholas, After the New Right (London, Heinemann, 1983).

Clarke, Janet, and Newman, John, The Managerial State (London, Sage, 1997).

Clarke, Janet, Gewirtz, Sharon and McLaghlin, Eugin, New Managerialism: New Welfare (London, Sage, 2000).

Fée, David, 'Le logement et l'Etat-Providence, 1979-1997', in A. Kober Smith and T. Whitton, L’Etat-Providence : Bilan de 18 années de pouvoir conservateur (1979-1997), Revue Française de Civilisation Britannique, IX : IV, pp. 133-149.

Forrest, Ray, 'The Privatisation of Collective Consumption', in M. Gottdiener, C. Pickvance (eds.), Urban Life in Transition, Urban Affairs Annual Reviews, vol. 39, London, Sage, 1991, pp. 169-195.

Hayes, Mark, The New Right in Britain, An Introduction to Theory and Practice (London, Pluto Press, 1994).

Hood, Christopher, 'The New Public Management in the 1980s, variations on a theme', Accounting Organisation and Society, 20 (1), 1995.

Home Affairs Committee, Evidence, 25 June 2013, Q207-23. 
House of Commons, Home Affairs Committee, Asylum Accommodation, Twelfth Report of Session 2016-17, HC 637 (London, HMSO, 2017).

House of Commons, Home Affairs Committee, Thirteenth Report of Session 2017-19, Asylum Accommodation: Replacing Compass, HC 1758 (London, HMSO, 2018).

ICIBI, An Inspection of the Home Office's Management of Asylum Accommodation Provision (London, ICIBI, 2018.

Jenkins, Simon, Thatcher and Sons: A Revolution in Three Acts (London, Penguin Books, 2007).

Kavanagh, Denis, Thatcherism and British Politics: The End of Consensus? (Oxford, OUP, 1987).

LeGrand, Julian and Robinson, Ray (eds.), Privatisation and the Welfare State (London, George Allen and Unwin, 1984.

Lister, Ruth, 'The Age of responsibility: social policy and citizenship in the early $21^{\text {st }}$ century', in Christopher Holden et al., Social Policy Review 23, 2011, pp. 63-85.

Ministry of Housing and Local Government, A New Deal for Social Housing CM 9671 (London, HMSO, 2017).

Murie, Alan, Forrest, Ray, Selling the Welfare State: The Privatisation of Public Housing, (London, Routledge, 1988).

Murie, Alan, The Right to Buy: Selling Off Public and Social Housing (Bristol, Policy Press, 2016).

National Audit Office, Compass Contracts for the provision of asylum seekers, HC 880 (London, NAO, 2014).

Pearl, Martyn and Zetter, Roger, 'From Refuge to Exclusion: Housing as an Instrument of Social Exclusion for Refugees and Asylum Seekers in the UK', in Peter Somerville and Andy Steele, 'Race', Housing and Social Exclusion (London: Jessica Kingsley, 2002), pp. 226-244.

Pollitt, Christopher, Managerialism and Public Services (Oxford, OUP, 1993).

Pierson, Christopher, Retrenchment and the Welfare State (Cambridge, CUP, 1994).

Pierson, Christopher, Beyond the Welfare State: the New Political Economy of Welfare, Cambridge, Polity, 2006 ed.

Secretary of State for the Home Department, The 1998 White Paper Fairer, Faster and Firmer, A Modern Approach to Immigration and Asylum, Cm 4018 (London, HMSO, 1998).

Shelter, No Place like Home? Adressing the Issues of Housing and Migration, Policy: Discussion Paper, London: Shelter, 2008.

Stumpf, Juliet, "The Crimmigration Crisis: Immigrants, Crime and Sovereign Power", American University Law Review, vol. 56, pp. 367- 420, 2006

Sturge, Georgina, Asylum Seekers, House of Commons Library, Number SNO1403, 2020

Twinch, Emily, ‘G4S misses asylum seekers deadline', Inside Housing, 16/11/2012

UK Parliament, Asylum Accommodation and Support, Schedule 2, statement of requirements, § 1.1.2., $<$ http://data.parliament.uk/DepositedPapers/Files/DEP2018-1112/AIRE_Contract-Schedule_2SoR_-_HOC_Published.pdf>, [12 June 2020].

Whitehead, Christine, 'Privatisation and Housing', in LEGRAND, J., ROBINSON, R. (eds.), Privatisation and the Welfare State (London, George Allen and Unwin, 1984). 
Williams, Mark, 'Under fire Housing Firm says Move away from Asylum Seekers Home Management is not because of Complaints, The Herald, 23 September 2016, <https:// www.heraldscotland.com/news/14759915.under-fire-housing-firm-says-move-away-fromasylum-seeker-home-management-is-not-because-of-complaints/> [12 June 2020].

\section{NOTES}

1. See for instance Deborah Phillips, "Moving Towards Integration: The Housing of Asylum Seekers and Refugees in Britain", Housing Studies, XXI: 4, 2006.

2. See for instance Steve Doughty, "Nine Asylum Seekers a week are found to be lying about being children in desperate bids to stay in Britain", The Daily Mail, 10 September 2018.

3. Refugee status is defined under Article 1 and 2 of the 1951 United Nations Convention and Protocol Relating to the Status of Refugees as "[...] any person who is outside the country of his nationality and is unable or, owing to such fear, is unwilling to avail himself of the protection of that country [...]" see UNHCR, United Nations Convention and Protocol Relating to the Status of Refugees, Article 1 and 2. The UK signed the Refugee Convention in 1954 and the Protocol in 1967. 4. Resettled people are granted refugee status while still living abroad and before being brought to the UK. For instance, Syrians are a category of resettled people and a target to resettle 20,000 Syrians by 2020 has been set by the UK government. Resettled people are not included in asylum seekers statistics. By 2018, there were four different resettlement schemes.

5. Although 'the new right' is not a term that everyone agrees with. See Denis Kavanagh, Thatcherism and British Politics: The End of Consensus? (Oxford, OUP, 1987).

6. Even though in practice the 'free market' is largely a myth. See Bernard Harcourt, The Illusion of Free Markets (Cambridge MA, Harvard University Press, 2011).

7. Nicholas Bosanquet, After the New Right (London, Heinemann, 1983), p. 5.

8. Ibid, p. 22.

9. Mark Hayes, The New Right in Britain, An Introduction to Theory and Practice (London, Pluto Press, London, 1994), p. 29.

10. Janet Clarke and John Newman, The Managerial State (London, Sage, 1997)

11. Julien LeGrand, Ray Robinson (eds.), Privatisation and the Welfare State (London, George Allen and Unwin, 1984), p. 4.

12. Simon Jenkins, Thatcher and Sons: A Revolution in Three Acts (London, Penguin Books, 2007)

13. As consumers and providers, see Christopher Pierson, Beyond the Welfare State: the New Political Economy of Welfare (Cambridge, Polity, 2006 ed.), p. 136.

14. Bosanquet, op. cit., p. 22.

15. LeGrand and Robinson, op.cit., p. 22.

16. Ray Forrest, 'The Privatisation of Collective Consumption', in M. Gottdiener, C. Pickvance (eds.), Urban Life in Transition, Urban Affairs Annual Reviews 39 (1991), p. 174.

17. Tenants Management Organisations were created in 1993 and Arm's Length Management Organisations in 2002. They were both designed to take the daily management of council housing away from councils.

18. Ibid.

19. John Clarke, Sharon Gewirtz, Eugene McLaughlin, New Managerialism, New Welfare (London, Sage, 2000).

20. Christopher Pollitt, Managerialism and Public Services (Oxford, OUP, 1993).

21. Christopher Hood, 'The New Public Management in the 1980s, variations on a theme', Accounting Organisation and Society, XX: I, 1995.

22. LeGrand and Robinson, op. cit., p. 69. 
23. The amount of money the government needs to borrow to make up the difference between what it spends and what it gets from taxes.

24. David Fée, « Le logement et l'Etat-Providence, 1979-1997 ", in A. Kober Smith and T. Whitton, L’Etat-Providence: Bilan de 18 années de pouvoir conservateur (1979-1997), Revue Française de Civilisation Britannique, IX : IV, pp. 133-149.

25. The Right to Buy policy was launched in 1980 and has consisted in giving sitting tenants the right to buy their council house/flat with ever larger discounts with each new Housing Act.

26. Christopher Pierson, Retrenchment and the Welfare State (Cambridge, CUP, 1994), p. 79.

27. Christine Whitehead, 'Privatisation and the Welfare State', in Julien LeGrand and Ray Robinson, op. cit., p. 120.

28. Alan Murie, Ray Forrest, Selling the Welfare State: The Privatisation of Public Housing (London, Routledge, 1988), p. 74.

29. MHLG, A New Deal for Social Housing Cm 9671 (London, HMSO, 2017), p. 17.

30. See <https://www.ethnicity-facts-figures.service.gov.uk/housing/social-housing/rentingfrom-a-local-authority-or-housing-association-social-housing/

latest\#: :text=households\%20with\%20higher\%20rates\%20of,Caribbean\%20(40\%25)\%20ethnic\%20groups> [1 September 2020].

31. Alan Murie, The Right to Buy: Selling Off Public and Social Housing (Bristol, Policy Press, 2016), p. 65.

32. Theresa May, the then Home Secretary declared in a statement to The Telegraph on 25 May 2012 that her aim was "to create here in Britain a really hostile environment for illegal migration, see The Telegraph, 'Theresa May's Interview: We are going to give illegal migrants a really hostile reception'.

33. Georgina Sturge, Asylum Statistics, House of Commons Library, Briefing Papers SN01403 (London, HMSO, 2020), p. 3.

34. Between 2014 and 2019, 25,493 people were resettled to the UK, mainly from Syria and the surrounding region. Resettlement programmes accounted for about $23 \%$ of the people granted humanitarian protection in the UK since 2014, Ibid.

35. Ibid.

36. Ibid., p. 20.

37. Ibid., p. 7.

38. Ibid., p. 10.

39. In May 2007, Margaret Hodge, then Minister for Work and Pensions, claimed that migrants were getting access to social housing at the expense of British households.

40. Shelter, No Place like Home? Addressing the Issue of Housing and Migration, Discussion Paper (London, Shelter, 2008), p. 6 and p. 11.

41. Martyn Pearl and Roger Zetter, 'From Refuge to Exclusion', Housing as an Instrument of Social Exclusion for Refugees and Asylum Seekers in the UK', in Peter Somerville and Andy Steele, 'Race', Housing and Social Exclusion (London, Jessica Langley Publishers, 2002), p. 227.

42. Ibid. p. 228.

43. Secretary of State for the Home Department, Fairer, Faster and Firmer, A Modern Approach to Immigration and Asylum, Cm 4018 (London, HMSO, 1998).

44. Ibid., p. 3.

45. Ibid.

46. Ruth Lister, 'The Age of responsibility: social policy and citizenship in the early $21^{\text {st }}$ century', in C. Holden et al., Social Policy Review 23, 2011, pp. 63-85.

47. Although a High Court ruling in October 1996 re-established the rights of in-country applicants if without means of their own, see Phillips, op. cit., p. 4.

48. Phillips, op. cit., p. 543. 
49. House of Commons Affairs Committee, Asylum Accommodation, HC 637 (London, HMSO, 2017), $\S 114$.

50. Namely a policy agenda combining immigration and asylum control and criminalisation measures, see Juliet Stumpf, "The Crimmigration Crisis: Immigrants, Crime and Sovereign Power", American University Law Review, vol. 56, pp. 367- 420, 2006 and A. Aliverti, Crimes of Mobility: Criminal Law and the Regulation of Immigration (London: Routledge, 2013).

51. House of Commons, 2017, op. cit., p. 43.

52. Ibid., p. 14.

53. Secretary of State for the Home Department, 1998, op. cit., § 8.6.

54. Phillips, op. cit., p. 4.

55. Interview 1 with former policy officer, West Midlands Migration Partnership, 7 February 2020.

56. Secretary of State for the Home Department, 1998, op. cit., § 8.23.

57. Ibid., § 3.5 .

58. Phillips, op. cit., p. 543.

59. House of Commons, 2017, op. cit., §1, p. 3.

60. House of Commons Home Affairs Committee, Asylum Accommodation: replacing COMPASS, HC 1758, London, HMSO, 2018, §2, p. 5.

61. House of Commons, 2017, op. cit. \$117, p. 45.

62. Ibid, §3.

63. <http://www.Serco.com/about> [1 September 2020].

64. Ibid.

65. <http://www.ready-homes.co.uk/index.php?page=who-we-are> [13 June 2020].

66. House of Commons, 2018, op. cit., p. 23.

67. National Audit Office, Compass Contracts for the provision of asylum seekers, HC 880, London, NAO, 2014, § 3.2.

68. House of Commons, op. cit., 2018, p. 21.

69. Ibid., p. 9.

70. Ibid., p. 20.

71. House of Commons, 2017, op. cit., p. 16.

72. Ibid., p. 9.

73. House of Commons, 2017, op. cit, p. 24.

74. ICIBI, An Inspection of the Home Office's Management of Asylum Accommodation Provision (London, ICIBI, 2018), §3.14.

75. Ibid., \$3.13.

76. House of Commons, 2018, op. cit., p. 14.

77. Ibid., p. 21.

78. House of Commons, 2017, op. cit., § 84 .

79. Ibid, $§ 85$.

80. Emily Twinch, "G4S misses Asylum Seekers Deadline”, Inside Housing, 16/11/12

81. Phillips, op. cit., p. 543.

82. House of Commons, 2018, op. cit. p. 28.

83. Ibid., p. 24.

84. <https://www.bbc.com/news/uk-scotland-50389904> [13 June 2020].

85. House of Commons, 2017, op. cit., p. 43.

86. Pearl and Zetter, op. cit., 2002, p. 240.

87. House of Commons, 2017, op. cit., p. 5.

88. UK Parliament, Asylum Accommodation and Support, Schedule 2, statement of requirements, $\S \quad$ 1.1.2., <http://data.parliament.uk/DepositedPapers/Files/DEP2018-1112/AIRE_ContractSchedule_2-SoR_-_HOC_Published.pdf> [12 June 2020]. 
89. Mark Williamson, 'Under fire Housing Firm says Move away from Asylum Seekers Home Management is not because of Complaints', The Herald, 23 September 2016, <https:// www.heraldscotland.com/news/14759915.under-fire-housing-firm-says-move-away-fromasylum-seeker-home-management-is-not-because-of-complaints/> [12 June 2020].

90. Home Affairs Committee, Evidence, 25 June 2013, Q207-23.

91. Interview 2 with current lead officer and assistant officer, West Midlands Migration Partnership, 7 February 2020.

92. Interview 1.

93. House of Commons, 2018, op. cit., pp. 25-30 and House of Commons, 2018, op. cit., p. 15.

94. <https://www.parliament.uk/business/publications/written-questions-answers-statements/ written-statement/Commons/2019-01-08/HCWS1237/> [1 September 2020].

95. <https://www.parliament.uk/business/publications/written-questions-answers-statements/ written-statement/Commons/2016-12-08/HCWS335/> [1 September 2020].

96. The Home Affairs committee was told the government would seek "the most economically advantageous tender", see House of Commons, 2018, op. cit., p. 28.

\section{ABSTRACTS}

The United Kingdom has been a pioneer regarding privatisation policies since the 1980s. This derives from the coming to power in the UK in 1979 of the New Right with the election of the Conservatives led by Margaret Thatcher. Privatisation has taken many forms and has spared no area of society or the economy. Housing has been at the forefront of the public services that have undergone privatisation for economic, political and practical reasons. Within the field of housing, the rules governing access to asylum accommodation have been altered since the 1990s and the provision of accommodation has shifted to the private sector since the 2010s. These transformations have had consequences on asylum seekers' housing conditions. Going over successive parliamentary reports on the matter, one cannot fail to wonder who are the winners and the losers of these reforms.

Le Royaume-Uni est un pionnier en matière de politiques de privatisation depuis les années 1980. Ce choix découle de l'arrivée au pouvoir en 1979 de la Nouvelle Droite en la personne de Margaret Thatcher. Cette politique de privatisation a pris des formes multiples et n'a épargné presqu'aucun pan de la société et de l'économie. Le logement figure au premier rang des services publics touchés par ces mesures pour des raisons économiques, politiques et pratiques. Au sein de ce domaine, les règles qui gouvernent l'accès des demandeurs d'asile au logement ont été modifiées depuis les années 1990 et la fourniture de logements a basculé dans le domaine privé depuis les années 2010. Ces transformations n'ont pas été sans conséquences sur les conditions de logement des demandeurs d'asile et à la lecture des multiples rapports parlementaires sur le sujet il convient de s'interroger sur les gagnants et perdants de ces mesures.

\section{INDEX}

Keywords: asylum, privatisation, housing, immigration, local government, accountability Mots-clés: asile, privatisation, logement, immigration, collectivités locales, comptable 


\section{AUTHOR}

\section{DAVID FÉE}

CREW,

Université Sorbonne Nouvelle, Paris

David Fée is professor of British Studies at the University of Sorbonne Nouvelle in Paris. He specialises in the study of housing and urban policies in the UK as well as the British welfare state. He is the author of many articles on housing and planning in the UK as well as a book on the housing crisis in the UK. His current topics of research include inequalities in the UK, and British and French New Towns from a comparative and international perspective. 